\title{
Government Assisted Programs and Unemployment Reduction in Developing Economies: A Study of Nigeria and Ghana
}

\author{
* Edwin Agwu
}

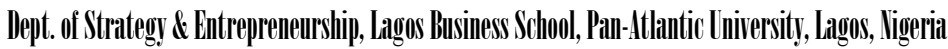

\begin{abstract}
This paper sets out to comparatively analyze various programs developed by the governments of Nigeria and Ghana towards alleviating unemployment. The inadequacies which have bedeviled these government assisted programs and their consequent failures warrant a review and reconsideration. The research employed qualitative case method with interviews as tools for data collection. Findings revealed a plethora of evidential facts with respect to perception of entrepreneurship in these countries which hinged on challenges such as inadequate funding, lack of requisite trainings, dearth of entrepreneurship education as well as the enabling environments. Most obvious among these challenges are the complete lack of governmental supports for the programs they propagated leading to the failure of various employment alleviation programs. This paper recommends the enactment of clear-cut policies by the governments under the leadership of a specialized ministry (ministry for entrepreneurship). Furthermore, a review and inclusion of entrepreneurship in the academic curriculum at all levels of the educational system will endear students to entrepreneurship studies. Finally, a holistic support of the organized private sectors in achieving a quantifiable target of full-fledged entrepreneurs within a decade will assist in unemployment reduction.

Keywords: Entrepreneurship, government assisted programs, unemployment reduction, business growth, Nigeria, Ghana

JEL:F43, H53, J64
\end{abstract}

One of the contemporary challenges facing sub-Saharan African leaders is unemployment among its citizens, especially among growing youths. Every year, there are increased numbers of graduates from higher institutions with the hope of finding paid jobs to cater for personal and family challenges (Inyang and Enuoh, 2009). These young men and women who are 'awaiting jobs' that are not guaranteed is the rationale for the high rate of social ills plaguing the societies. In the face of joblessness, these youths exert their energies and high wired intelligence into criminal activities, thereby perpetrating all forms of social ills. Unemployment within the context of the Sub-Saharan part of Africa is considered a big challenge with more than 40 percent unemployed population (Ayoade and Agwu, 2016). This is apparent in the number of young men and women of working-class ages, who are prepared to work, unfortunately there is no work to engage in. World Bank (2013) reported that young people who are within the age of employment in Africa have been disadvantaged due to lack of very healthy organized private sectors that can drive employment for economic growth. This situation, 
in which people look for a wage job but could not find, has resulted in societal dysfunctional activities (Yeboah and Jayne, 2018) such as terrorism, kidnapping and various socio-economic vices. New generations of African youths who live in urban centers are categorized as the most educated; yet, many of these educated youths are finding the prospect of getting employment a mirage (Obi and Okeke, 2017). Furthermore, majority of another category of young people live in the rural areas and small towns are faced with poorer standards of living and inability to access basic necessities of life. These groups also struggle to find paid employment that allows them to have basic needs of livelihoods. It is on record that the rate of idle hands and minds in the world is on the increase and unemployment, if not challenged in the Africa continent by various governments, may pose the risk of brain drain, i.e., smart, aggressive people leaving their native countries for employment opportunities elsewhere due to increased urge to seek for greener pastures. Providing social, economic and demographic employment opportunities for youths requires in-depth understanding of pathways that will help drive self-employment that will be beneficial to the self-employed individuals and government institutions. Therefore, introducing entrepreneurship to these teeming populations of young adults can serve as an alternative means of income generation and ultimately stem the tidal waves of unemployment within the developing economies in particular and the world in general. Generally, entrepreneurship is regarded as an important tool for economic development among developed nations, and a means through which employment generation is heightened. Researchers and policy makers have called for urgent attention and focus on how to make entrepreneurship an important tool for economic growth in all countries (Acs and Audretsch, 2005). This is because, entrepreneurship drives innovation and creativity, increases employment and meets new demands (Oladele, Akeke and Oladunjoye, 2011).

The challenge of unemployment has been regarded as multidimensional and causes unimaginable ripple effects, with evidential proofs. Obi and Okeke (2017) asserts that entrepreneurial practices could lead to decline in unemployment growth. Individuals that have benefitted from government programs aimed at reducing unemployment has either not maximized such opportunities or has given up adapting the interventions due to lack of drive to try out the new ventures. These unyielding approaches to solving this ever-increasing unemployment, means that there are other plausible internal factors that may be responsible for these challenges. Researches available have investigated and reported mixed results on the role of entrepreneurships as a broad term to reduce unemployment in developing economies (Gielnik et al., 2015). Based on the extensive literature reviewed, there are dearth of literature that have observed how entrepreneurship serves as a tool for unemployment reduction on comparative levels, hence, this study fills this vacuum by investigating how entrepreneurship can serve as a tool for unemployment reduction in both Nigeria and Ghana and 
explores how different characteristics of entrepreneurships can be increased in both countries for the benefits of the citizens. The questions begging for answers are:

1. Can entrepreneurship serve as a tool for unemployment reduction in Nigeria and Ghana?

2. What are the different characteristics that may enhance entrepreneurial acceptance and adoption in both countries?

A model has been developed in this study with the aim of exploring how entrepreneurship can be used as a strategic tool to reduce unemployment in Sub-Saharan Africa in general, with special focus on Nigeria and Ghana. The application of this model will result in academics, practitioners and policy makers being informed about the dispositional factors that hinder entrepreneurial programs. This paper therefore contributes to the extant literature on comparative government assisted programs and unemployment reduction practices in developing economies. It is hoped that it will also serve as a reference document for academics, practitioners and policy makers in various developing economies with respect to unemployment issues and applicable solutions. The next section dwells on the related literature, which compared the government assisted programs in Nigeria and Ghana; while there are differences in operational modalities by both governments, the aims are significantly the same. The Theory of Reasoned Action (TRA) and Theory of Planned behavior (TPB) were used in the assessment of the demand and supply of these entrepreneurship programs by the citizens. The qualitative case study approach employed threw up a plethora of issues based on the discussions gathered from the participants. The paper ended with discussions and recommendations for practitioners and policy makers.

\section{LITERATURE REVIEW}

\section{Unemployment in African Economies}

Sub-Saharan Africa is considered as fast growing in population with an estimated increase from 12 percent in 2015 to 23 percent by 2050 (United Nations, 2016). This population comprises of sixty-two (62\%) percent of young adults of below twenty-five (25) and a labor force growing at 3 percent per year (World Bank, 2013). It is estimated that each year until 2035, about 17 million young Africans will become of working age (Losch, 2012). This growing population of workforce offers chances for economic development if their talents are well exploited for economic expansion (Yeboah and Jayne, 2018). There have been reports of rapid economic growth of about 4.5 percent increase per year in Sub-Saharan Africa since the last fifteen years, yet the economies still depend on primary commodities for export purposes (World Bank, 2013). Countries like Nigeria and Ghana with abundant 
natural resources and noticeable growth still find it difficult to reduce the scourge of unemployment (Obi and Okeke, 2017). Sub-Saharan Africa shares almost the same characteristics with East Asia, but when compared in terms of economic growth, evidences show that the economic boom resulting to unemployment reductions in East Asia is yet to be visible or take-off in Sub-Sahara Africa (World Bank, 2013). In the light of these facts, researchers such as Dike (2009), Salami (2013), Agu, Anidiobu and Ezinwa (2016), have proposed entrepreneurship as a panacea to these challenges.

\section{Government Assisted Entrepreneurial Programs in Nigeria}

Beyond the essential facts about stability of political institutions in Sub-Saharan Africa, various entrepreneurial programs have been established in order to curb the threat posed by persistent unemployment. In Nigeria, government programs such as Startup Nigeria (SN), National Poverty Eradication Program (SPEP), Small and Medium Industries Equity Investment Scheme (SMIES), Youth Entrepreneurship Support Program (YESP), Social Intervention Fund (SIF), were set up to alleviate the challenge of unemployment, yet, these programs have generated mixed reactions (Fadahunsi and Rosa, 2002; Agwu, Onwuegbuzie and Ezeifeka, 2017). Challenges associated with these programs are centered on government policies that restrict large number of prospective entrepreneurs from accessing these programs (Katrine and Pia, 2010). For instance, some entrepreneurs stated that the government programs are characterized by just political undertone and have not been developed to suit prospective entrepreneurs' interest. This is evident in form of restriction on certain key raw materials or outright ban, withdrawal of subsidies, increase in taxes etc. (Ayoade and Agwu, 2016; Oboh and Nwachukwu, 2018).

\section{Government Assisted Entrepreneurial Programs in Ghana}

In Ghana, Entrepreneurs Incubators and Acceleration Program (EIAP), and National Youth Employment

Program (NYEP) were created to curb unemployment, but the acceptance level of these programs among entrepreneurs and prospective entrepreneurs have been low (Katrine and Pia, 2010). Although, there has been sound economic management which has yielded high growths in economic opportunities; policies for economic stability are reinforced in order to have sustained poverty and unemployment reduction, nonetheless, there have been indications that these programs are abstract and not favorable to the development of local entrepreneurs (Robson and Obeng, 2008). There have been high interest rates associated with loans disbursed to existing entrepreneurs and prospective entrepreneurs are scared of embarking on such journey, and would prefer to remain jobless. There are also claims that government policies are favorable to foreign enterprises as opposed to local entrepreneurs. Furthermore, the challenges of key infrastructures, such as roads, health facilities, 


\begin{abstract}
Agwu
water and electricity as well challenges associated with registration of new businesses due to corruption and bureaucratic processes are causes for the low acceptability of such entrepreneurial programs in Ghana.

\section{Entrepreneurial Drive}

Intrinsic urge of prospective entrepreneurs can help them develop high self-efficacy and acquire the required knowledge and skills to develop new initiatives (Baum and Locke, 2004). Drive is a crucial construct in entrepreneurship, because it is often regarded as a variety of characteristics that compel an individual to pursue a unique path relentlessly (Frese, 2009). Starting a new business as an entrepreneur requires continuous action because of its lengthy and challenging processes (Frese, 2009; Gartner, 1988). Launching a new business takes several years in which the entrepreneur is required to devote times and efforts (Reynolds and Curtin, 2008), thus, it is essential for entrepreneurs to expend unlimited efforts in starting new ventures (Foo, Uy and Baron, 2009). Researchers such as Baum, Locke and Smith (2001), Cardon and Stevens, (2009), and Mbugua (2017) posit that there are varying characteristics that can fuel an individual to start a new entrepreneurial venture - such as entrepreneurial drive. The internal factor that enhances entrepreneurial behavior has been classified as mental cognitive processes of thoughts (Iyigun and Owen, 1999; Taiwo et al., 2016). The ability to engage in positive thinking (cognitive mental processes) is also regarded as one of the ways through which success is predicted among entrepreneurs (Singh and Gibbs, 2013). This internal drive also referred to as a motivator that leads to high confidence in entrepreneurs' ability to venture into new businesses (Mbugua, 2017). Based on Maslow hierarchy of needs, lower needs, such as, food, clothing and shelter, which are luxuries to potential entrepreneurs as a result of unemployment, can drive them to engage in entrepreneurship and make them move to other levels of the hierarchy such as self-esteem and self-actualization, (Ensley, Carland and Carland, 2000). Additionally, Singh and Gibbs (2013) concluded that entrepreneurial drive helps potential entrepreneurs scale through challenges of startups and then develop the attitude of employers rather than that of the employees or job-seekers, therefore, maximizing their innate potentials through external opportunities (Ensley et al., 2000; Nwachukwu, Kolog and Uzoka, 2018).
\end{abstract}

\title{
Theoretical Underpinnings
}

\section{-Theory of Reasoned Action and Theory of Planned Behavior}

This study is rooted in Ajzen and Fishbein's (1980) theory of reasoned action (TRA) which examines the relationship between attitudes and behaviors. The theory holds that attitudes towards a behavior are evaluated within the context of subjective norms. These norms, which are the individual's percepti- 
on of social pressures to engage or not to engage in a particular behavior, are predictive of behavioral intents and ultimately determines whether the behavior is exhibited or not. The attitudes and subjective norms related to entrepreneurial activities may be a significant factor that drives individuals to engage in entrepreneurial adventures. Thus, the attitudinal and behavioral mechanisms within the scope of entrepreneurship can shape or influence internal drive to engage in entrepreneurship.

Theory of reasoned action (TRA) was extended by Ajzen (1991) through the inclusion of perceived behavioral control. This extension, known as the theory of planned behavior (TPB), holds that attitudes towards a behavior are evaluated within the context of subjective norms and perceived behavioral control. With respect to perceived behavioral control, individuals assess their ability regarding the difficulty or ease in performing a behavior. This assessment is reflective of past experiences and is based on perceptions about resources availability and anticipated obstacles (Gist and Mitchell, 1992; Golembiewski, 2018). Thus, theory of planned behavior holds that intention will be greatest when an individual holds a favorable attitude toward a behavior, experiences strong subjective norms regarding that behavior, and anticipates that they can successfully perform the behavior.

Figure 1 provides an example of the application of TPB in relation to entrepreneurial drive and unemployment. Using this model, the focus of most unemployment reduction programs and the effect on unemployment is viewed through the point of views of the individuals and their attitudinal disposition towards the programs that is being targeted, as well as perceived support during and after the intervention programs (subjective norms) and entrepreneurial drive (perceived behavioral control). Entrepreneurial drive is defined in this context as those innate forces that propel an individual to take action towards starting an entrepreneurial adventure. These innate forces may make an individual engage in prior entrepreneurial activities including writing a business plan, looking for a building or equipment, saving money, or developing a product or service (Aldrich and Martinez, 2001). These activities can be characterized as innate activities that drive an actual behavior, and are not viewed as the actual entrepreneurial behaviors (Reynolds et al., 2004).

Attitudes to the behavior: The attitudes towards starting new businesses by individuals are fraught with several snags ranging from capital accumulation, location selection, required skills, etc. Many individuals see these hurdles as mountains they cannot surmount, hence they settle for any form of salary paid jobs where it exists.

Subjective Norms: The role of social pressures comes into play as there are always high expectations from all and sundry. There is a severe need not to be idle, hence the constant and unending call and great expectation to the government from the citizens. They see the government as the big brother and one that must provide facilities. Unfortunately, the government cannot provide jobs to all its citizens, 
hence the big gap.

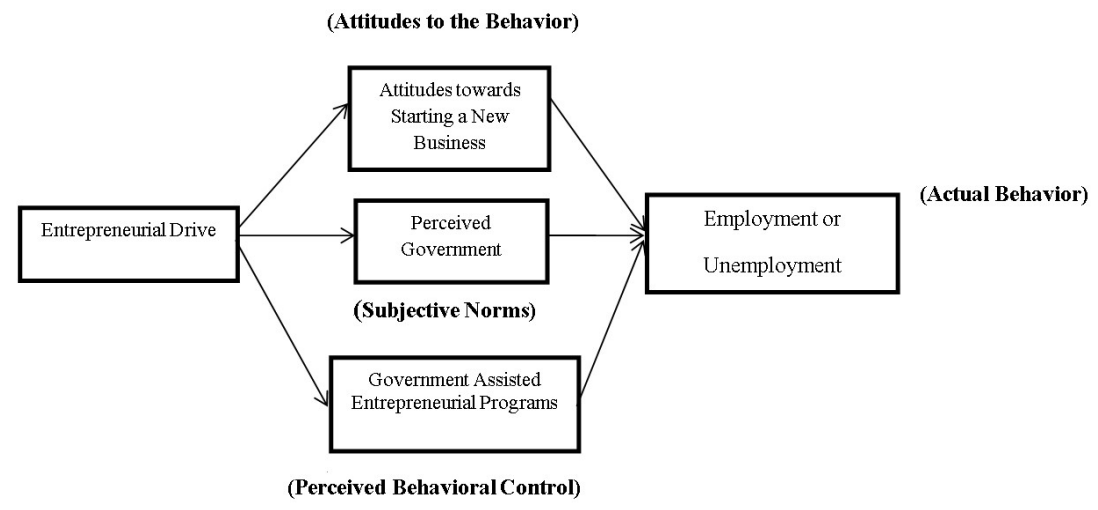

Source: Ajzen (1991); Ajzen \& Fishbein (1980)

Figure 1. A Model of Entrepreneurial Drive and Unemployment

Perceived behavioral control: This is in relation to all government assisted entrepreneurial programs. Government on its part believes that providing the enabling environment and adequate policies will assist citizens to look away from white collar jobs and invest on the available resources and acquire relevant skills to drive the economy through entrepreneurship. Hence several programs are rolled out to assist the citizens in findings their feet.

Actual Behavior: This is the final but it is either employment or unemployment. While some citizens' will, despite the hurdles and unending bureaucracies, take opportunity of the available programs to better themselves, others out of fear, may not, therefore, remain unemployed for as long as it takes.

\section{Entrepreneurship and Unemployment Reduction}

Although entrepreneurship may lead to low unemployment rate, the relationship is such that, unemployment may lead to increase or decrease in entrepreneurship and this points to the dynamic relationship that exists among the two constructs (Faria, Cuestas and Mourelle, 2008). Even though there is a dissection between these constructs, researchers differ on the relationship between unemployment and entrepreneurial activities (Audretsch, Carree and Thurik, 2001; Baptista, Van Stel and Thurik, 2006). This has led to different studies investigating whether increase in entrepreneurship has led to unemployment reduction or whether unemployment drives individuals to engage in entrepreneurial activities, and this has led to the ambiguous results emanating from the study of the two constructs.

Some studies (Ayoade and Agwu, 2016; Farlie, 2011) found that there is a positive relationship 
between unemployment and entrepreneurship, while oppositely, Pfeiffer and Reize (2000), and Oladele et al. (2011) found negative correlation between the two constructs. Other researchers (Carree and Thurik, 2003) were not convinced by their study results to either accept or refute the claim that the two constructs of unemployment and entrepreneurship are either positively or negatively related. Røed and Skogstrøm (2014) viewed unemployment as a potentially destructive experience that may lower intuitive drive to engage in productivity activities and suggested that inability to be engaged with a wage job, displacement after getting a job can undermine workers' future employment opportunities and earnings, and this raises their likelihood of entering disability programs, and also raises their risk of divorce and even raises their risks of early deaths (Chidiebere, lloanya and Udunze, 2014). Conversely, Røed and Skogstrøm (2014) also posited that unemployment also triggers creativity; this is noticeable when unemployed individuals think outside their limited environments to develop the ability to capitalize on their challenges for innovation, thereby creating something out of nothing, and fostering entrepreneurship opportunity of setting up a new business.

The unemployed and some under-employed individuals tends to possess lower motivational zeal of human and social capital and entrepreneurial talents, and may also lack the innate drive to start and or sustain a new firm, which may lead to either not starting or early exits (Baptista et al., 2006). High levels of unemployment may be considered an opportunity to start a new business if the right capacity is available in terms of zeal and preparation. This has been found to correlate with high economic growth leading to a high number of entrepreneurial opportunities (Verheul et al., 2006).

This lack of clarity between unemployment and entrepreneurship exists because most often the secondary data have been used in previous studies to get their findings. For example, Carree (2002) found that lagged unemployment appears to be a significant push factor of business ownership. Wood et al. (2012) suggested that unemployment is characterized by a number of unique dimensions that may drive the unemployed to bear risks and this will be based on his/her evaluation of the desirability and feasibility of available entrepreneurship tasks. These risk assessments, desirability and feasibility cognitions are important because they affect the person's openness to pursuing entrepreneurship as a career option. According to Taiwo et al. (2016), for the unemployed, taking such a risk is worthwhile because it is considered as a last option to be utilized.

Entrepreneurial drive could also be considered a result of the pull and push effects which may be produced by a sustainable economy (Yeboah and Jayne, 2018). Pull factors are internal conditions that force people into entrepreneurship because of the lack of viable alternatives (Dike, 2009). Economic crises and periods of high unemployment may ignite entrepreneurial drive in individuals towards self-employment because of lack of other opportunities (Dawson and Henley, 2012). Also, pull factors may attract and drive potential entrepreneurs towards creating businesses as a way of 


\begin{abstract}
Agwu
seizing market opportunities. Building on the context of the global entrepreneurship monitor (GEM) database, Reynolds et al. (2005) distinguished between push and pull innate drives by introducing the concept of opportunity and necessity entrepreneurship. Push motivation drives necessity entrepreneurship, whereas pull motivation forms the basis for entrepreneurial opportunity to create start-ups. The importance of these distinctions affects how an individual entrepreneur runs his or her venture which may in turn affect their outputs (Acs, Desai and Hessels, 2008). This study sheds light on some of the issues and challenges associated with training groups of individuals who are thinking of starting a business from the stand point of government assisted programs. In drawing together the themes, unemployed individuals engaging in entrepreneurship will need a distinguishing characteristic (e.g., entrepreneurial drive) that will influence their decisions to engage in entrepreneurial activities. Entrepreneurial drive falls into the pull and push factors of positive motivations for individuals irrespective of the external interventions (funds) received.
\end{abstract}

Based on these syntheses, a framework similar to the conceptual work of Halvorsen and MorrowHowell (2016) is proposed in Figure 1. The framework is specific to unemployed individuals that may have received or are considered to receive or benefitted from government assisted entrepreneurial programs towards self-employment or entrepreneurship. It proposes that individual entrepreneurial drive influences the decision to become self-employed in later life and that training, support and entrepreneurial experiences help to build on these innate characteristics. The framework also adapts Marič , Jeraj and Pavlin's (2010) framework comprising three factors that influence entrepreneurial activity; drive (motivation), skills, and opportunity. Drive in this context refers to the internal factor that helps individual place value on entrepreneurship and its desirability and feasibility as a career and employment option; skills refer to the technical, business, and entrepreneurial abilities and know-how; while opportunity refers to the external factors that serve as motivators, in this case, government intervention programs. Despite the robustness of these theories, the realities may in fact not hold much hope for the unemployed. And these depends on so many factors such as the content of the government programs, the processes of delivery, the perception of the recipients, and the cultural issues that may be attached. The present political and economic turbulences in the economies of Nigeria and Ghana in particular and Africa in general make it imperative for the teeming young population which constitutes a significant pool of potential entrepreneurs to opt for anything other than government assisted programs. The theory of reasoned action (TRA) and theory of planned behavior (TPB) were, therefore, employed to determine the extent to which these programs appeal to these teeming young populations and determine the ways in which they perceive these programs. The questions to find answers to in this regard are - Do the already established government assisted programs meet the needs of these young men and women or are they just white elephant projects 
floated by governments to siphon money from the economies? If the perceptions of these young adults are positive, why are most still unemployed?

\section{METHODOLOGY}

\section{-Study Design}

This study adopted a qualitative case approach because of the nature of the populations of the study samples as well as variables under study. Semi-structured interviews with open ended questions were used as the main techniques for obtaining qualitative information through individual interviews. Furthermore, this method enabled the examination of each country's governmental programs in detail. The method also allows a replication logic which tends to yield better grounded theories and more generalizable results than those from single case studies (Yin 2011). The dearth of qualitative approach into the subject matter was a motivator for the qualitative case study method in order to probe into additional motivators that may not be covered within the scope of standardized instruments of quantitative questionnaires. One advantage of using qualitative case method with interviews as the instrument of data collection was that rapport can be built in depth with each of the participant (Merriam 2009; Palys, 2003; Yin 2011). The purpose of the interview was to gain a deep insight into the factors affecting the fundamental issues that drive entrepreneurial motivations as well as factors that mitigates the successes of entrepreneurial adventures from the participants' points of view. The interviews provided a very good opportunity for very close communication as well as understanding between the researcher and the participants. These made it possible for the researcher to extract the relevant information whose accessibility was impossible via structured questionnaires. The personal interviews also made it possible for the researcher to come face-to-face with the participants, thereby, had the opportunity to assess their expressions in the course of the discussions. A total of ten (10) participants from each country (Nigeria and Ghana) were interviewed. This made the number of the participants for the study twenty (20). The duration of interview ranged from 25 to 35 minutes with an average of 30 minutes. Consent was sought from the interviewees so that their voice will be recorded.

\section{-Sample Selection and Justification}

Twenty petty traders and artisans from various parts of Nigeria and Ghana resident in both Lagos and Nigeria were selected. These participants were chosen using the following criteria; first, a high level of active handwork was required. And all the participants must be self-employed. Secondly, these participants were richly diversified in terms of sector of activities, petty trading in different materials, plumbing, driving, carpentry, tailoring, etc. Therefore, the reason for the usage of this qualitative study 


\begin{abstract}
Agwu
was to gain a deep insight into how these government assisted programs have really assisted in unemployment reductions in both countries, therefore, the use of ten participants from each country was justified as Saunders et al., (2009:35), stressed that "we need to capture the lived experiences of individuals and their stories, much like the choreographer who crafts a dance". Based on this premise, the researcher immersed himself in the lived experiences of the participants in order to understand what they understand, feel their heart-beats as well as experience things in their own way.
\end{abstract}

Ethical Considerations: The opportunity to conduct researches using human participants is not a privilege but necessitates a heightened sense of responsibility (Yin, 2011), therefore, in accordance with the ethical requirements of using human beings for research purposes, it is very important for all information provided by all participants to be kept highly confidential. In order to protect their anonymity, pseudonyms were used and participants were apprised of all information relating to the research work. This included the reason for the research, where it was to be conducted and over what time frame, what was involved, and whom it would benefit. All participants were assured of anonymity through the use of a coding scheme developed by the researcher to ensure participant confidentiality. A confidential agreement for both participants was signed by all who were involved in this research.

Reliability and Validity: Easterby-Smith et al., (2008) stated that reliability involves the replication of same result or outcomes by different researchers. In order to increase the reliability of this research, the qualitative case study method adopted, ensured the comparative analysis of the information provided. To further increase the reliability of the research work, the researcher re-visited some of the participants to reconfirm their transcribed words and some were discussed via telephone calls at the request of the participants. Furthermore, Saunders et al., (2007) stressed that validity on the other hand relates to findings, and also seeks to understand if the findings are in fact what they are; furthermore, this study was subjected to internal and external validities.

Sampling Technique: Purposive sampling technique was used in the selection of participants for this study and they were selected by the virtue of their entrepreneurial activities in the Nigeria and Ghana. It was expected that they would have offered the desired information needed to explore the research questions. Participants were asked to discuss what drives them to engage in entrepreneurial activities and their perception about government assisted programs. Those who have not been successful after benefitting from entrepreneurial programs were also identified to understand what contributed to their failures. All the interviews were audiotaped, transcribed and later analyzed separately. Themes were derived from the data based on the meanings captured in the content of the researchers' objectives (Ryan and Bernard, 2003). The sample characteristics are shown in Table 1 (see Appendix-I). 


\section{Information Analysis}

Data gathered were collated in line with Glesne (2006). The data were categorized into subsections in line with the research objectives and questions. This provided means for comparing and contrasting the data from different sources. Data that fit into the themes were categorized while data that did not fit into the theme were not, as they were considered extraneous. Content analysis was used to categorize information obtained from both countries. Themed data were then broken down into relevant comments, contrasting words and ideas, and these emerged as themes.

\section{RESULTS}

Findings from the analyzed data revealed that different factors drive entrepreneurs and affect their perceptions about the efficacy of programs designed to aid these entrepreneurial drives. Although government programs in both countries have roles to play in alleviating the challenges of unemployment among their citizens who are regarded as potential entrepreneurs, it was expected by the author that these programs would have been accepted by those the programs are designed for. This will then be followed by implementation of the various program objectives. Unfortunately, this is not the case as the program participants are still more like those who did not participate. The programs were, therefore, considered ineffective. There are agencies saddled with the responsibilities of ensuring that these programs are accessed by potential or existing entrepreneurs. Findings, however, revealed a multi-layer dense of bureaucratic protocols as evidenced by the interviewees, these effectively killed the urges to participate by many applicants as so many paper works are required to be considered, and some participants need to bribe his way through; and this is beyond most participants. These programs are designed such that individuals are identified, registered and trained to become entrepreneurs. This is in a bid to reduce over dependence on sparse government jobs. However, there have been lamentations as regards the efficacy of these programs, as most of the participants complained that virtually all the programs are politically charged, hence, they could not meet the proposed needs for which they were introduced. Below are the thematic proofs that were derived from the data collected, analyzed and interpreted:

Entrepreneurial Motivating Factors: According to the participants, those who get benefits from the government programs are individuals who are connected with the government officers and can meet their selfish demands, hence, individuals with real drives and ideas to establish businesses are disadvantaged. On the question of what drives them to engage in entrepreneurial activities was aptly by Participant 6, a Nigerian graduate of accounting, managing a roadside medium provision shop: "The economic challenge of this country is nothing to write home about. Government jobs are not easy 


\section{Agwu}

to come by even when you are qualified except you have a god-father. And becoming an entrepreneur is a herculean task, yet it is crystal clear that there are no other options of getting other means to fend for myself and my family". I struggled to set this up with family finance after several attempts with the government assisted programs without success. The programs were not worth the while. I tried several of them but no success. Participant 17, 36 years old Ghanaian, who owns a retail pharmacy shop spoke in the same vein: "I was driven by the fact that I want to help others get a living. I want to be an employer rather than being employed. I detest being ordered around by someone I may or may not be better than. Also, I detest depending on someone for income. I prefer to be innovative in my own way without being restricted and I am doing fine with what I have got right now. This is my driving force. I refuse to attend any of the government programs because I cannot beg the government officials or pay them. Moreover, the process is cumbersome and frustrating. Some go to the center everyday but come back empty handed. Participant 2, a Nigerian and an information technologist (techpreneur) also explained further: "Not everyone enjoys the routine that characterized government jobs. I am thrilled by competition and this drives me in engaging in entrepreneurial activities such as the one I am doing today. If I am beaten in my quest, I strategize again. I love to win because entrepreneurship is all about winning". This was further buttressed by Participant 4, a Nigerian spare-part seller: "/ am trained to work with various teams. I see myself as an effective team leader. I think my training as a team leader will be enervated if I work for establishment that does not appreciate such potentials. Hence, in order to avoid the waste of my talents, I switched to starting my own business which I think is doing well because of this acquired skills".

From the above, it can be deduced that many of the entrepreneurs have a drive that spur them to engage in entrepreneurial activities. Despite the economic, social and environmental challenges, these individuals still find it interesting to become entrepreneurs and have since turned away from the government assisted programs. This finding is in consonance with the works of Singh and Gibbs (2013). They opined that internal drive is a factor that is positively related to entrepreneurial success and further supports the theories utilized.

\section{Government Factors}

This revolves around the participants' views of the various government entrepreneurial programs which were aimed at unemployment reduction; and how the effectiveness of these programs has affected or influenced their entrepreneurial drive or other entrepreneurs around them. The participants responded in discordant tones with the general opinion that many of the government programs are for the elite groups; individuals with the right entrepreneurial intentions and drives are not identified and given the opportunity to benefit from it, hence, the reason for low unemployment reduction. Their views were 
captured thus: Participant 10 from Nigeria, a graduate, and a taxi driver stated that: "They are just programs on paper. I don't believe any of these programs have the tendency to reduce unemployment I have never and will never believe in government entrepreneurial programs as a panacea to unemployment. I believe that individuals can be spurred by challenges around them, rather than waiting for unguaranteed assistance from the government". Participant 19, a graduate and car wash owner in Ghana: "Who you know is the real question when government entrepreneurial programs are being rolled out. Countless numbers of times people disqualified from benefiting from such programs and their place given to someone who will use the resources for purposes for which the programs are not meant for. I am a successful entrepreneur today and I do not see the benefit of any of the government programs yielding any positive results". In consonance with above two, Participant 5, a Nigerian stressed that: "The programs from government are good, but they cannot defeat unemployment. Potential entrepreneurs should be identified to know what programs are to be developed to suit their needs. Most of the ongoing government entrepreneurial programs are meant for campaign purposes only and to portray the government as effective while they are actually very inefficient. Only those they consider party members are qualified to benefit. I have spent six months trying to get loans from government because of their bureaucratic processes. I don't think these programs can help reduce unemployment if the right people are not trained nor supported for entrepreneurial activities". Participants 8 from Nigeria and 14 from Ghana echoed similar thoughts: "Government programs are good and sound very nice. But entrepreneurs should not depend on these programs. I cannot really say if these programs are beneficial or not, but I am certain that those who are motivated to becoming entrepreneurs won't wait for government to train or assist them. Entrepreneur is about innate tendencies and how to convert these to real time solutions. If you are motivated by yourself or the needs around you, then you are ready to become an indomitable entrepreneur".

\section{External Mitigating Factors}

The challenges the participants faced as entrepreneurs was another issue that received decisive responses. Most of the study participants pointed out that, the challenge of motivating factors such as availability of funds is a major problem. Some of them opined that funding from government are disbursed to individuals without business plan and ideas, and at the end the funds are wasted and most are plowed into what they were not originally meant for. Below are highlights of the respondents' views on external mitigating factors:

Participant 20, an estate agent in Ghana stressed that: "most banks will not give you loans, and those ready to give will tie it around exorbitant interests with load of paper works; and without funds, no 
business can thrive. If there are funds available, there will be more successful entrepreneurs". Participant 4, a Nigerian Saloon owner corroborated the above statement by stating that: "Funds and raw materials are key external mitigating factors. Most entrepreneurs operate with borrowed finances with high collateral demand. At the end this, funds are used to service what does not bring in profits. For example, the money / use in trying to generate electricity is big enough to reduce my operational cost to 42 percent. This is a huge factor"

This study identified some of the factors associated with the increase in unemployment and the inability of the government programs to identify individuals with entrepreneurial drives. Based on these, the findings validated the theoretical framework adopted for this study. If entrepreneurial drives of potential entrepreneurs are thoroughly examined before interventions are provided, there will be positive perceptual acceptances of the programs which will in turn reduce unemployment. The methodology employed in this study and the findings from all the data collected clearly indicated that entrepreneurial drive is a key factor to watch out for when planning or designing programs for potential entrepreneurs.

\section{DISCUSSION}

The issues profiled in this paper are definitely not unique to Nigeria or Africa as evidenced by the works of various authors such as Katrine and Pia (2010) in Ghana, Mbugua, (2017) in Kenya, Baptista et al., (2006) in Portugal, and Reynolds and Curtin (2008) in the United States of America. The focus on entrepreneurship has never been more important as it is today in Sub-Saharan Africa and indeed in all developing economies, bearing in mind that there is need for more innovative and entrepreneurial activities to drive these initiatives. For example, in China, India, Singapore as well as the UK, wider Europe and even the North Americas today, most factory workers make more money than while-collar professionals in some firms. The upside for white-collar workers is higher but some college graduates will go without work rather than go to the factory. Thus, as societies push forward to educate individuals, what becomes of these individuals needs detailed scrutiny with respect to what they will eventually do after the four walls of the classroom, therefore, the act of education alone does not push the society forward. These school leavers, individually and collectively will eventually take the society to a new level through entrepreneurship activities. To this end, this study provides an informed assessment and adequate understanding of how entrepreneurial drives can lead to unemployment reduction, thereby corroborating the works of Baum and Locke (2004), Dawson and Henley (2012), and Agu et al. (2016). It is evident that effective plans to reduce unemployment should be targeted at those with innate propensity to engage in entrepreneurial activities. This is because, these individuals with entrepreneurial drives will withstand different pressures that may ordinarily discourage others from 
persevering during their entrepreneurial adventures. Rather than being discouraged, they are galvanized to develop innovative ideas to mitigate such challenges. From the strategic policy angle, entrepreneurial programs must be designed to align with prospective entrepreneurs' interests, the work of Dawson and Henley (2012) corroborates this assertion. Funds made available by the government should be monitored to ascertain that it is used for what it is meant for. Consequently, soft loans should be provided for existing or prospective entrepreneurs to ensure that their drives are not killed because of lack of funds to carry on with their business plans. Lastly, the establishment of the Federal Department of Entrepreneurship will play a significant role and will be highly important in the current dispensation to ensure the Federal government's direct focus on entrepreneurship issues. The current practices of leaving such very important functions to governmental agencies and departments that are not well funded and poorly supervised should be stopped and replaced with a functional and wellfunded Federal Departments of Entrepreneurship.

\section{LIMITATIONS AND FUTURE DIRECTIONS}

This study is based on qualitative case study method, with interviews as instrument for data collection. Future studies can adopt the use of quantitative or mixed method approaches in assessing the entrepreneurial drives of potential entrepreneurs, and also explore its effectiveness through longitudinal studies in different regions. Relevant theories and contexts can also be employed to further deepen the understanding of the factors behind the driving spirits of these courageous tribes.

\section{REFERENCES}

Acs, Z. \& Audretsch, D. (2005). Introduction to the handbook of entrepreneurship research. In Acs, Z. \& Audretsch, D. (Eds.) Handbook of Entrepreneurship Research: 3- 8. Boston: Springer.

Acs, Z. J., Desai, S. \& Hessels, J. (2008). Entrepreneurship, economic development and institutions. Small Business Economics, 31(3): 219-234

Agu, B. O., Anidiobu, G. A. \& Ezinwa, C. E. (2016). Entrepreneurship education: A panacea for unemployment in Nigeria. NGJournal of Social Development, 5(2): 1-11.

Agwu, M. E., Onwuegbuzie, H. N. \& Ezeifeka, P. (2017). Impact of entrepreneurship education on new ventures creation - A case study. Advances in Social Sciences Research Journal, 4(25): 98-114.

Ajzen, I. (1991). The theory of planned behavior. Organizational Behavior and Human Decision Processes, 50(2): $179-211$.

Ajzen, I. \& Fishbein, M. (1980). Understanding attitudes and predicting social behavior. Englewood Cliffs, NJ: Prentice Hall.

Aldrich, H. E. \& Martinez, M. A. (2001). Many are called, but few are chosen: An evolutionary perspective for the study of entrepreneurship. Entrepreneurship Theory and Practice, 25(4): 41-56.

Audretsch, D. B., Carree, M. A. \& Thurik, A. R. (2001). Does entrepreneurship reduce unemployment?. No. 01-074/3. Tinbergen Institute discussion paper.

Ayoade, O. E. \& Agwu, M. E., (2016), Employment generation through entrepreneurial development: The Nigerian experience. British Journal of Economics, Management \& Trade, 11(3): 1-14.

Baptista, R., van Stel, A. \& Thurik, A. R. (2006). Entrepreneurship, industrial restructuring and unemployment in Portugal. Entrepreneurship, Growth, and Innovation: 223-241. Boston, MA: Springer.

Baum, J. R. \& Locke, E. A. (2004). The relationship of entrepreneurial traits, skill, and motivation to subsequent venture growth. Journal of Applied Psychology, 89(4): 587-600.

Baum, J. R., Locke, E. A. \& Smith, K. G. (2001). A multidimensional model of venture growth. Academy of Management Journal, 44(2): 292-303

Cardon, M. S. \& Stevens, C. E. (2009). The discriminant validity of entrepreneurial passion. Academy of Management Proceedings: 1-6. Briarcliff Manor, NY: Academy of Management. 
Carree, M. A. \& Thurik, A. R. (2003). The impact of entrepreneurship on economic growth. In Handbook of entrepreneurship research: 437-471. Boston, MA: Springer.

Chidiebere, O. N., lloanya, K. \& Udunze, U. (2014). Youth unemployment and entrepreneurship development: Challenges and prospects in Nigeria. Kuwait Chapter of the Arabian Journal of Business and Management Review, 4(4): $20-35$.

Dawson, C. \& Henley, A. (2012). "Push" versus "pull" entrepreneurship: An ambiguous distinction? International Journal of Entrepreneurial Behavior and Research, 18(6): 697-719.

Dike, V. E. (2009). Addressing youth unemployment and poverty in Nigeria: A call for action, not rhetoric. Journal of Sustainable Development in Africa, 11(3): 129-151.

Ensley, M. D., Carland, J. W. \& Carland, J. C. (2000). Investigating the existence of the lead entrepreneur. Journal of Small Business Management, 38(4): 59-77

Easterby-Smith, M., Thorpe, R. \& Lowe, A. 2004. Management Research ( ${ }^{\text {nd }}$ ed.). London: Sage Publications.

Fadahunsi, A. \& Rosa, P. (2002). Entrepreneurship and illegality: insights from the Nigerian cross-border trade. Journal of Business Venturing, 17(5): 397-429.

Fairlie, R. (2011), Entrepreneurship, economic conditions, and the great recession. Institute for the Study of Labor (IZA), Discussion Paper no. 5725.

Faria, J. R., Cuestas, J. C. \& Mourelle, E. (2010). Entrepreneurship and unemployment: A nonlinear bidirectional causality? Economic Modelling, 27(5): 1282-1291.

Foo, M. D., Uy, M. A. \& Baron, R. A. (2009). How do feelings influence effort? An empirical study of entrepreneurs' affects and venture effort. Journal of Applied Psychology, 94(4): 1086-1094.

Frese, M. (2009). Towards a psychology of entrepreneurship-an action theory perspective. Foundations and Trends in Entrepreneurship, 5(6): 437-496.

Gartner, W. B. (1988). Who is an entrepreneur? Is the wrong question. American Journal of Small Business, 12(4): 11-32.

Gielnik, M. M., Spitzmuller, M., Klemann A. \& Frese, M. (2015). I put in my effort, therefore, I am passionate: Investigating the path from effort to passion in entrepreneurship. Academy Journal of Management, 58(4): 1012-1031.

Gist, M. E., \& Mitchell, T. R. (1992). Self-efficacy: A theoretical analysis of its determinants and malleability. Academy of Management review, 17(2): 183-211

Glesne, C. (2006). Becoming a qualitative researcher: An introduction ( ${ }^{\text {rd }}$ ed.) New York: Longman.

Golembiewski, R. (2018). Current topics in management: Volume 7. Routledge.

Halvorsen, C. J. \& Morrow-Howell, N. (2016). A conceptual framework on self-employment in later life: Toward a research agenda. Work, Aging and Retirement, 3(4): 313-324.

Inyang, B. \& Enuoh, R. (2009). Entrepreneurial competencies: The missing link to successful entrepreneurship in Nigeria International Business Research, 2(2): 62-71.

lyigun, M. F. \& Owen, A. L. (1999). Entrepreneurs, professionals, and growth. Journal of Economic Growth, 4(2): 213-232.

Katrine, B. \& Pia, R. (2010). Youth entrepreneurship in Accra, Ghana: The role of education and social networks in opportunity development. Published master thesis, Copenhagen Business School, Denmark.

Losch, B. (2012). Agriculture: The key to the employment challenge. Perspective No. 19. Montpellier: CIRAD.

Marič , M., Jeraj, M. \& Pavlin, J. (2010). Entrepreneurship as a solution to the unemployment problem, $\breve{S}$ kola Biznisa, 2, 8997.

Mbugua, N. W. (2017). Influence of entrepreneurial drive on growth of selected micro and small enterprises in Nairobi county, Kenya. Strategic Journal of Business and Change Management, 4(4): 1-14.

Merriam, S. B. (2009). Qualitative research: A guide to design and implementation. San Francisco: Jossey-Bass.

Nwachukwu, C., Kolog, E. \& Uzoka, P. (2018). The link between SMEs death rate, unemployment and GDP: Evidence from the Visegrad countries. Management Strategies, 2(40): 35-44

Obi, I. E. \& Okeke, T. (2017). Psychological readiness and entrepreneurial intentions of unemployed graduates: What difference can vocational psychologists make? African Journal of Education, Science and Technology, 3(4): $203-209$.

Oboh, I. \& Nwachukwu, C. E. (2018). Entrepreneurial support in Nigeria: A review paper.

Management Strategies, 2(40): 45-51.

Oladele, P., Akeke, N. \& O. Oladunjoye, (2011). Entrepreneurship development: A panacea for unemployment reduction in Nigeria, Journal of Emerging Trends in Economics and Management Sciences, 2(4): 251-256.

Palys, T. (2003). Research decisions: Quantitative and qualitative perspectives (3 ${ }^{\text {rd }}$ ed.). Toronto: Nelson.

Pfeiffer, F. \& Reize, F. (2000). Business start-ups by the unemployed: An econometric analysis based on firm data. Labour Economics, 7, 629-663.

Reynolds, P. D. \& Curtin, R. T. (2008). Business creation in the United States: Panel study of entrepreneurial dynamics II initial assessment. Foundations and Trends in Entrepreneurship, 4(3): 155-307.

Reynolds, P. D., Carter, N. M., Gartner, W. B. \& Greene, P. G. (2004). The prevalence of nascent entrepreneurs in the United States: Evidence from the panel study of entrepreneurial dynamics. Small Business Economics, 23(4): 263-284.

Robson, P. J. \& Obeng, B. A. (2008). The barriers to growth in Ghana. Small Business Economics, 30(4): 385-403.

Røed, K. \& Skogstrøm, J. F. (2014). Unemployment insurance and entrepreneurship. Labour, 28(4): 430-448.

Ryan, G.W. \& Bernard, H.R. (2003). Techniques to identify themes. Field Methods. 15(1): 85-109.

Salami, C. G. E. (2013). Youth unemployment in Nigeria: A time for creative intervention. International Journal of Business and Marketing Management, $1(2): 18-26$.

Saunders, M., Lewis, P. \& Thornhill, A., (2009). Research Methods for business students (5 ${ }^{\text {th }}$ Ed.). Essex: Pearson Education.

Singh, R. P. \& Gibbs, S. R. (2013). Opportunity recognition processes of black entrepreneurs. Journal of Small Business and Entrepreneurship, 26(6): 643-659. 
International Journal of Management, Economics and Social Sciences

Taiwo, J.N., Agwu, M.E., Adetiloye, \& Afolabi. (2016) Financing women entrepreneurs and employment generation - A case study of microfinance banks. European Journal of Social Sciences, 52(1): 112-126.

United Nations. (2016). World urbanization prospects, the 2014 revision. New York. Retrieved May 30, 2019, from https://esa.un.org/unpd/wup/DataQuery/.

Verheul, I., Van Stel, A., Thurik, R. \& Urbano, D. (2006). The relationship between business ownership and unemployment in Spain: A matter of quantity or quality? Estudios de Economía Aplicada, 24(2): 105-127.

Wood, L. A., Kendal, R. L. \& Flynn, E. G. (2012). Context-dependent model-based biases in cultural transmission: Children's imitation is affected by model age over model knowledge state. Evolution and Human Behavior, 33, 387-394.

World Bank (2013). Online poverty data base. Retrieve June 03, 2019, from http://povertydata.worldbank.org/poverty/home/.

Yeboah, F. K. \& Jayne, T. S. (2018). Africa's evolving employment trends. The Journal of Development Studies, 54(5): 803832.

Yin, R. K. (2011). Qualitative research from start to finish. New York, NY: Guilford. 
Agwu

Appendix-I

\begin{tabular}{ccc}
\hline Variables & Categories & Number of Participants \\
\hline Gender & Male & 12 \\
& Female & 8 \\
Age & $18-25$ & 4 \\
& $26-35$ & 8 \\
& $36-45$ & 5 \\
Level of education & $46-55$ & 2 \\
& 56 and above & 1 \\
& No formal Education & 6 \\
Marital status & Certificate/Diploma & 3 \\
& First Degree & 5 \\
& Masters & 6 \\
Year of entrepreneurial experience & Never Married & 7 \\
& Married & 11 \\
& Divorced & 2 \\
& $1-10$ & 8 \\
& $11-20$ & 9 \\
\hline
\end{tabular}

Table 1. Details of Participants in Nigeria and Ghana 